\title{
IB school libraries as international- minded learning spaces and environments
}

\author{
Anthony Tilke PhD \\ High School Librarian [from August 2015] \\ The American School of The Hague \\ Rijksstraatweg 200 \\ 2241 BX Wassenaar \\ Netherlands \\ atilke@ash.nl
}

\begin{abstract}
:
The International Baccalaureate Organization (IB) offers educational programs to schools world-wide. Originally established for international schools, programs are now typically offered in a variety of public and private educational institutions in many countries. The IB has developed four programs, covering a continuum of education from early years to courses for students aged 18 years of age. Programs are largely constructivist-based and IB 'big ideas' include inquiry, a holistic view of the learner (IB Learner Profile), international-mindedness and academic honesty, yet the role of the library, overall, is not as clearly identified as may be expected, given factors friendly to a library and information sector paradigm. This professional paper reviews IB documentation and thinking, identifies opportunities where the library can support and contribute to the programs and identifies good practice, focusing on conference themes of the school library as a learning space, learning environment and as a 'window on the world'.
\end{abstract}

Keywords: International Baccalaureate, inquiry, constructivist programs, international-mindedness

\section{Introduction}

To review the premise that the IB school library reflects international-mindedness, this paper provides background context for the International Baccalaureate, outlines its key ideas and philosophy and looks for references to library and librarian support in such documentation. Typical roles of library and librarian support throughout and beyond the IB continuum of education are outlined, before looking at the potential offered by new thinking and manifestations of the school library concept.

An international-mindedness approach to education is a key principle of the International Baccalaureate Organization (IBO or IB), which has developed curricula globally for a continuum of primary-secondary education. These curricula are the: 
- Primary Years Programme (PYP)

- Middle Years Programme (MYP)

- Diploma Programme (DP or IBDP)

- Career-related Programme (IBCP)

Therefore, the organization has created curricula for students aged from early years to 18 years of age. The Diploma Programme was originally the sole program of the IB and was created over 50 years ago, specifically for the needs of international schools. These schools were typically established in various countries for the children of expatriate families or those who moved from country to country, due to employment reasons. Since the mid-1990s, other programs have been developed by the IB. Today, IB curricula are offered in different types of schools, such as state or public schools, those created by different government policies, independent or private schools, and international schools.

Schools do not need to provide all IB programs, they can offer one or more. They can also offer a program as an option, alongside others, for students of a particular cohort (more typical at the Diploma level). But, irrespective of specific program offerings, schools need to accept philosophical 'big ideas' of the IB, including a focus on the learner (as exemplified through its Learner Profile), academic honesty, language, inquiry approaches to learning, and international-mindedness.

\section{IB philosophical ideas}

There are several areas where IB philosophical thinking have been developed:

- Academic honesty

Rather than the more negative connotations associated with the term plagiarism, the IB prefers a more holistic and positive term: academic honesty. Here, students are expected, indeed required, to have positive, ethical and principled approaches to using information to develop their lines of inquiry and knowledge-making, and to guide their conduct as scholars. However, it is important to note that, until recently, the focus and requirements for academic honesty specifically referred to the Diploma Programme (for students aged 16-18 years of age), whereas now there is a greater expectation that academic honesty principles will begin much earlier in a student's school career, and therefore be relevant to students who are experiencing the PYP and/or the MYP. (International Baccalaureate Organization, 2014b)

- Inquiry approaches to learning/Approaches to Teaching and Learning Inquiry by individual students is a key aspect of IB programs, whether as discrete units, or through the concluding project for each program. This is common to the PYP (where it is called the Exhibition), the MYP (Personal Project), the IBCP (Reflective Project), and the IBDP (Extended Essay) and can be regarded as significant, almost 'rites of passage' concluding elements of IB programs. Throughout, inquiry in the IB programs is "intellectually demanding at the appropriate developmental and/or alternative linguistic level of the individual student" (Hickey, 2011, p. 71). Closely allied to inquiry is the need to inculcate a student desire for curiosity and wonder (Barell, 2013), and where aspects such as critical thinking, problem-solving and creativity (Drapeau, 2014) are important attributes to develop. These and other skills and attributes are reflected in Approaches to Teaching and Learning, which are identified for each IB program. 
- International-mindedness

The term is the IB's own, in preference to terms such as interculturism or multiculturalism, though there will be overlap, and its stance is outlined in documentation (International Baccalaureate Organization, 2008). How a school develops and reflects internationalmindedness will be dependent on context and situation. It can include celebrating cultures and different national characteristics and achievements. It can include support for mother tongue and community languages (International Baccalaureate Organization, 2012). It can also include looking at various issues and challenges in a global context, on the understanding that we all inhabit a 'global village' (Roberts, 2009). Whatever the approach or approaches taken by a school, it is a cornerstone of IB thinking.

\section{- Language}

The IB stance on language ranges through linguistic, cultural and societal aspects.

Furthermore, 'the role of language is valued as central to developing critical thinking, which is essential for the cultivation of intercultural awareness, international-mindedness and global citizenship', so it is an important over-arching and linking concept. (International Baccalaureate Organization, 2011, p. 3)

\section{- Learner Profile}

The IB Learner Profile, originally a set of 10 statements of skills and qualities that students should develop as part of ongoing (indeed, lifelong) learning, is applicable to all IB programs (International Baccalaureate Organization, 2013).

These 'building-blocks' for an IB school are aspects that librarians, reading the above for a first time, would easily be able to find links or possible contributions from a library perspective. Are such library contributions identified in IB thinking or rather documentation (being manifestations of IB thinking)?

\section{Library and librarian in IB documentation}

Over the years, librarians who work with and support the IB programs have been aware of (and been concerned by) lack of reference to either the school library or librarian in IB documentation and literature (Tilke, 2009). One example will suffice to show the trend. In 2012, the IB published a collection of papers entitled The changing face of international education: challenges for the IB (Walker, 2012), which contains interesting and helpful contributions to suggest future development of the IB. However, the words library and librarian are not mentioned, neither are related terms, such as resources, skills, information literacy, etc. The book deals with the big ideas of the IB, not least inquiry, so one would expect at least mention of the contribution of the school library/ian in possibly one section, but such is not the case.

Nevertheless, there are isolated references to library/ian in various IB documents that focus on key areas of IB thinking:

- Language and learning in IB programs (International Baccalaureate Organization, 2011)

- Academic honesty - since 2014, various documents 
- Approaches to Teaching and Learning - various documents for specific programs. (Related to this is the over-arching concept and document of skills and aptitudes that students should develop - the Learner Profile.)

- Programme Standards and Practices (International Baccalaureate Organization, 2014a)

The briefest mention of the words library/ian in these IB documents occurs in the Standards and Practices document (2014a), which is a key set of principles used to evaluate schools when they apply to offer IB programs and for regular reviews after that time. It is more concerned about the provision of a school library, though suggests that the existence of a well-regulated school library is a significant factor in the establishment of an IB-friendly learning environment.

The language document (2011) also contains brief mention of library/ians, but this does indicate a role for the school librarian (being a member of the school's review committee on language policy), rather than simply passive resource provision.

In the area of academic honesty, there are a number of references to the librarian - teaching and supporting students with regard to researching and referencing ethically and, at one stage, this constituted the most developed role of the librarian in IB documentation. (International Baccalaureate Organization, 2014b)

Approaches to teaching and learning (ATL) is an over-arching term used to identify skills and aptitudes which students should develop, and these are program-specific, as reflected in the separate documents for the 'ATLs'. Relevant skills and examples of support that can be provided by a library/ian are lightly drawn in these documents.

One other significant IB idea is that of the concluding project, which is common to all the programs. Whilst this paper is concerned with documents common to all IB programs and there are individual documents for each concluding project (and with varying references to the role of the library and librarian), the concept is an over-arching one. (Barrett, Green \& Tilke, 2011; Hickey, 2011)

Within documentation relating to individual programs, there are also some references to libraries/librarians, but they have been somewhat ad hoc. It is outside the focus of this paper to examine each document produced by the IB and would change as new documents are produced, and would be repetitive. Suffice to say that a stated identification of roles of the school library and, more importantly, the librarian, are slightly and variably identified in IB documentation. As documentation provides the detail about IB approaches to learning, and which prompts a school to act (and guides individual teachers), such lack of identity must be a concern. Such concern exists because the IB promotes the idea of inquiry as central to its practices and the programs are considered to be constructivist-friendly, and both inquiry and constructivism have strong associations with the school library concept (Tilke, 2009; 2011c).

Nevertheless, to be fair, the situation is improving, though there are still relatively few overt references to library/ians in IB documentation. To be fairer still, this is not a situation peculiar to the IB. Experience and observation over the years of educational literature shows this to be a feature of the literature (Tilke, 2009). Again, one recent example will suffice. Reflecting a major educational concern for authentic learning, one recent title from a major US 
educational organization entitled Authentic Learning in the digital age: engaging students through inquiry (Pahomov, 2014) does not include LIS terms (library, librarian, resources, information literacy) in the index, and there appears to be only one passing (negative) reference to the school library in the book, which is also concerned with inquiry and research. In short, a disconnect may exist between school library literature and that of general or other educational literature (Tilke, 2011c).

\section{Roles of the library and librarian in IB programs}

In spite of this disconnect between IB documents and library support for the IB programs, there are roles for the library and librarian in support of IB programs. However, librarians and others need to tease these of documents or interpret the documents accordingly.

Another way is to look at good practice in school librarianship in general, and see whether this can be applied to the 'IB school library', which is a construct largely in a library and information science (LIS) paradigm. Using both these approaches, it can be suggested that typical roles for a school library and librarian in support of IB programs are as follows:

The library

- Resource provision to support the school's curriculum

- Reflecting international-mindedness - world literature, mother tongue, countries and culture - a 'window on the world'

- Environment to practice, value and celebrate students' involvement with the IB Learner Profile

- A place - virtual and physical - to support inquiry and research

- Affective domain - a place to think, to reflect, to be calm, to be balanced - a mindful environment

- A physical statement of IB values and philosophy (e.g. international-mindedness)

- A place to support literacy and reading development

- A place to engender a love of story, creative narratives and reading, often reflecting a multi-cultural and multi-lingual environment.

It should be acknowledged that the role of the librarian is likely to be distinct from the school library per se (Green, 2007). For an 'IB librarian' - and this again is from an LIS perspective - the focus of activity is likely to be:

The librarian

- Manages, promotes and encourages use of quality information and resources - for students, parents and teachers

- Co-facilitator in inquiry and research processes

- Scaffolds support - physical and digital - for students, in support of their skill development

- Teaches research and referencing skills - and critical thinking

- Contributes to the academic honesty awareness, practices and standards in the school

- Provides and promotes tools and knowledge products for students and teachers, through technological know-how, writing skills, curating and collection-development strategies

- Tutor and affective support for students in terms of research and student project management 
- Supports literacy development, including digital and information literacy, in relation to Approaches to Teaching and Learning (ATL) documentation for each program

- Supports curriculum development, e.g. co-planning and evolution of units

- Acts as a trainer and other means of school-based professional development support

- Specifically supports the concluding project(s) of a/each program (but support is not limited to these albeit important stages)

- Work with relevant IB program coordinator and other personnel who are tasked with developing specific areas of the IB programs.

Whilst this is a general approach common to the programs, and thus has been treated as a whole, there will be differences or variations between age groups and different programs. This might range, for instance, from supporting group dynamics (and therefore elements of the Learner Profile) in the PYP Exhibition, to teaching academic writing for the DP Extended Essay, and curating digital resources for DP students (DP Librarian, 2015).

Against these optimal job functions, there are inevitably limitations, including funding, also the caliber, status, training and experience of library staff, plus limited time.

Another factor is the perception of others, which may well limit what the librarian can do in support of individual IB programs. That the IB school library has been an under-used resource was identified by Clark (1995); she spoke to a large conference of IB head teachers in 1995 about possible contributions that a school library and its librarian could make to the then one IB program (Diploma). In a mostly positive review of a book on the school library and the IBDP (Tilke, 2011), the reviewer, a head teacher, considered that it was rather the Internet more than school libraries that had more impact on DP students (Bunnell, 2012), which suggests (for whatever reason) low expectations of school library performance or contributions. Huisman (2015) commented that principals may have 'archaic perceptions of school librarians' based on their own experiences as school students (p. 460); Tilke (2009) found that IBDP teachers perceived, used and valued school libraries largely dependent on their memories of being secondary school students themselves. As IB staffers are typically former teachers and senior school administrators, it is likely that they would generally have similar views to IB school-based colleagues, thus policy and direction of IB thinking and philosophy is being largely developed by schools and IB staff. Therefore, an IB environment where change-makers have limited experience of the utility of school libraries/ians may be said to exist.

To change this situation, it may be that a mixture of performance, evidence and/or advocacy about the impact of school libraries could be effective. To assist, it may be helpful to have a statement/paper in IB documentation about the role of the librarian. As Tilke (2009) found, such statements need to be in specific IB curricular documentation, as that is where the majority of IB educators look for information. (Arguing for such inclusion in curricular documentation is an aim of various individuals and small groups of librarians operating in an IB environment, who seek to be in dialogue with IB regional offices.) 


\section{Continuum of IB education and beyond}

The IB has developed the concept of a continuum of education through IB programs, as exemplified by the Learner Profile. However, a student's education may well not end there, as most DP graduates go on to tertiary education.

Skills and aptitudes developed by students during IB years can help them in higher education - such experiences include time management, research and inquiry skills (Tilke, 2011c). Indeed, the concluding projects of each program provides a spring-board to help students in the next stage of education.

In the case of the DP, the Extended Essay especially helps to give exposure to and experience of the type of working expected in tertiary education (Barrett, Green \& Tilke, 2011). Such good practice needs to be contextualized, given various studies which have identified that many students entering tertiary education did not have requisite skills to conduct tertiary-level research (e.g. Head \& Eisenberg, 2011) and various (non-IB) examples of the benefits of secondary students conducting research through helpful interventions by the school librarian and using a relevantly-resourced school library (e.g. Huisman, 2015).

Thus, school librarians may need to take a longer view when trying to identify benefits or utility of librarian input into inquiry, research and referencing skills of IB students.

\section{School library as learning space and environment}

In 1994, Cordoba articulated a vision for the role of the 'IB library', which focused on supporting research and cultural, i.e. international-mindedness, aspects of the IB program. It needs to be remembered that - in 1994 - digital means of information were limited and the IB was then concerned only with one program - the Diploma.

It is assumed that the educational landscape has significantly changed since then. Certainly, this is the case for the IBO, not least because it now operates four programs or curricula and has articulated and extended its key areas of philosophy.

Therefore, it may be that the Cordoban model of an IB school library may not be totally relevant today. Although Cordoba (1994) hypothesized research and cultural roles for an IB school library, because there is not a blue-print for what an IB library looks like or should do, various current trends in the wider school library world could be adopted by IB school libraries, but would they be relevant? Whilst digital space has taken the attention of the school library and information sector community, the use of the physical space has had a renaissance, as schools look anew about how to use their school library physical space. This is to do with the relative merits of physical and digital resources, and newer ways of teaching and learning.

Attention has been given over recent years to new ways of using the space occupied by the school library (Johnson, 2013), moving from a static resource collection, with traditional (quiet) study facilities, where the librarian is seen as a custodian and supervisor of space and students, to a more creative, flexible space, with the librarian adopting a more proactive and interactive role. Specific developments include a digital only concept of the school library, a 
learning or information commons approach, and makerspace (or variations, though this is mostly of nomenclature) (Whisken, 2012).

One approach could be do look at the features of each different manifestation of the school library and justify its adoption in support of IB curricula. A more holistic approach however would be to look at the essential features of IB curricula, identify possible contributions from the school library per se, and then look at how the school library needs to be constituted to best achieve such a result. A variable factor in this is the school itself - its organization, structure, size, pedagogical approaches, etc., will all be contributory factors. Therefore, as discussed above, the key features of IB programs are:

- Inquiry, contributing to authentic, collaborative learning

- A holistic learner (IB Learner Profile)

- Principled expectations and integrity (Academic Honesty)

- International-mindedness

- Language(s)

These aspects provide the IB starting-points, and should be the factors that schools focus on (together with much more detail in the Programme Standards and Practices document (2014a)) when considering how relevant existing school library/ian support is and, where relevant, how library and librarian support can be improved for the benefit of student learning and the particular IB program.

From the above, we can extrapolate various key activities and patterns of use, which may well focus on use of the library space for the following:

- Collaborative small group work in the library

- Individuals and groups creating new knowledge in the library, both conceptually and using various technological tools

- Making student products to show and communicate this new learning and knowledge

- Library as viewing and exhibition area

- Showing materials, resources and information to stimulate learning

- Displaying and exhibiting materials to promote new thinking and knowledge

- Making technological tools (e.g. libguides) to use in the library and elsewhere

- Venue for people to be expert witnesses for students

- Celebrating language and literacy and promoting the concept of voluntary, sustained reading as a pleasurable activity

- Teaching, practicing, scaffolding and using skills and aptitudes, not least in support of academic honesty

- In addition to teaching research skills and processes to classes in the library, the Librarian teaches and demonstrates technological applications in classrooms and other areas of the school

- Physical resources go to other areas of the school

- Individual research

- Individual thinking and study

- Quiet spaces

- Private reading 
Many, if not all, of these learning activities will happen simultaneously. There will also be the daily use of a school library to consider - as well as formal lesson times, libraries are typically very busy before and after the formal school day, and during recesses. Also, users need to be factored in - teachers and parents, as well as students. Additionally, allowance needs to be made where IB programs are part of various curricula/courses offered to students.

Once possible activities have been identified, a conservative school will want to look at what sort of activities it is comfortable with in its library, as some of these activities are competing, and be different from educator expectations and experiences of school libraries. Conversely, a more progressively-inclined school will probably look at what needs to be done to accomplish relevant learning activities in its library, having decided on an over-arching library mission or policy sentence.

In some ways, focusing the use of the school library on IB curricula is not radically different from supporting other curricula that seeks to offer authentic learning that is creative and socially constructivist in approach. That different models of school libraries have been developed elsewhere, means that various experiences can be used to identify optimum school library facilities to support IB programs.

\section{Conclusion}

IB programs offer holistic, globally-relevant learning experiences to students. These programs are guided by key philosophical and pedagogical ideas from the parent organization, the International Baccalaureate. Greater synergy needs to exist between IB thinking and the contribution of school libraries and librarians to support effective learning in an IB context. However, there are opportunities to be levered to create effective library support in the existing IB school-based infrastructure. By examining key IB documentation, major features of IB learning can be identified and used to inform the development of creative library environments, as manifested in various library development models, such as learning or information commons and makerspaces. The aim is that the school library/ian provides relevant services and facilities not only in physical and digital spaces, but also informing psychological and philosophical spaces of schools, educators and the IB.

\section{References}

Barell, J. 2013. "Did you ever wonder? Fostering curiosity here, there and everywhere." Cardiff, UK: International Baccalaureate Organization.

Barratt, Y., Green, G., \& Tilke, A. 2011, May. "Between the pages.” IB World, 62, 25.

Bunnell, T. 2012. "Book review: International Baccalaureate diploma program and the school library." Journal of Research in International Education, 11, 105-106.

Clark, C. 1995. "The school library: an under-used resource for the IB program?" IB World, 9, 43-46. 
Cordoba, C.A. 1994, April. "El rol de la biblioteca escolar en el Bachillerato Internacional." IB World, 5, 36-37.

DP Librarian's public library. 2015. "Diigo [knowledge management tool]." Retrieved from https://www.diigo.com/user/Dplibrarian

Drapeau, P. 2014. "Sparking student creativity: practical ways to promote innovative thinking and problem solving." Alexandria, VA: Association for Supervision and Curriculum Development.

Green, G. 2007, March. "New role of the teacher librarian: changes and challenges." Paper presented at the International Baccalaureate Asia Pacific Region Teacher Conference on Information Literacy. Retrieved from http://www.ibo.org/ibap/conference/documents/GaryGreen-ReinventingtheRoleofTeacherLibrarian.pdf

Head, A., \& Eisenberg, M. 2011. "How college students use the Web to conduct everyday life research." First Monday, 16(4). doi:10.5210/fm.v16i4.3484

Hickey, A. 2011. "Developing inquiries.” In G. Walker (Ed.), The changing face of international education: challenges for the IB (pp. 70-85). Cardiff, UK: International Baccalaureate Organization.

Huisman, R. 2015. "Library as place in urban high schools: connecting college readiness to librarian intervention and community partnerships." ACRL 2015 Proceedings. Retrieved from http://www.ala.org/acrl/sites/ala.org.acrl/files/content/conferences/confsandpreconf s/2015/Huisman.pdf

International Baccalaureate Organization. 2008. "Towards a continuum of international education." Cardiff, UK: International Baccalaureate Organization.

International Baccalaureate Organization. 2011. "Language and learning in IB programs." Cardiff, UK: International Baccalaureate Organization.

International Baccalaureate Organization. 2012. "An IB educator's story about the role of librarians in multilingual learning communities (Learning Stories)." Retrieved from http://www.isgr.se/nn13/pdf/Roleoflibrarians.pdf

International Baccalaureate Organization. 2013. "IB Learner Profile." Retrieved from http://www.ibo.org/contentassets/fd82f70643ef4086b7d3f292cc214962/learnerprofile-en.pdf

International Baccalaureate Organization. 2014a. "Standards and practices." Cardiff, UK: International Baccalaureate Organization. Retrieved from http://www.ibo.org/globalassets/publications/become-an-ibschool/programmestandardsandpractices.pdf 
International Baccalaureate Organization. 2014b. "Academic honesty in the IB educational context." Cardiff, UK: International Baccalaureate Organization. Retrieved from http://www.ibo.org/globalassets/digital-tookit/brochures/academic-honesty-iben.pdf

Johnson, D. 2013, October. "Power up! The new school library." Educational Leadership, 71(2). Retrieved from http://www.ascd.org/publications/educationalleadership/oct13/vol71/num02/The-New-School-Library.aspx

Pahomov, Larissa. 2014). "Authentic learning in the digital age: engaging students through inquiry." Alexandria, VA: Association for Supervision and Curriculum Development.

Roberts, B. 2009. "Educating for global citizenship: a practical guide for schools." Cardiff, UK: International Baccalaureate Organization.

Tilke, A. 2009. "The Impact of an International School Library on the International Baccalaureate Diploma Programme: A Constructivist Grounded Theory Approach." Unpublished Ph.D. diss. Wagga Wagga, NSW, Australia: Charles Sturt University.

Tilke, A. 2011a. "The International Baccalaureate Diploma Program: what it means to a school library and librarian." School Library Monthly, 27 (5), 8-10.

Tilke, A. 2011b. "The International Baccalaureate Diploma program and the school library." San Jose, CA: Libraries Unlimited.

Tilke, A. 2011c. "Supporting the school and the IB diploma community through the school library." In M. Hayden \& J. Thompson (Eds). Taking the IB Diploma Programme Forward (pp.117-127). Woodbridge, Suffolk, UK: John Catt Educational Ltd.

Walker, G. 2011. "The changing face of international education: challenges for the IB." Cardiff, UK: International Baccalaureate Organization.

Whisken, A. 2012. "Library learning spaces: one school library's initial design brief." Synergy, 10(2). Retrieved from http://www.slav.vic.edu.au/synergy/volume-10-number-22012/learning-landscapes/258-library-learning-spaces-one-school-librarys-initialdesign-brief.html

Note on IB documents

Because there are so many individual IB documents, this paper has focused on documents that are generally relevant to more than one IB program and/or are available through the Internet. It should be appreciated that a number of IB documents are only available on the IB Online Curriculum Centre (OCC), which is a password-protected digital space. For readers not familiar with IB documentation, a brochure that gives a succinct overview is available at http://www.ibo.org/globalassets/digital-tookit/brochures/ib-continuum-brochure-en.pdf 


\section{Biographical note}

Anthony Tilke has spent nearly 20 years in the international school sector, in Asia and Europe, and with major IB schools, including Yokohama International School, Japan, and the International School of Amsterdam, The Netherlands. He has worked with three IB programs: PYP, MYP and DP. His doctoral thesis (from Charles Sturt University, Australia) focused on impact of an international school library on the IB Diploma Programme, and which was accepted without amendment. This inspired the writing of his book about the Diploma Programme and the school library/ian for ABC-CLIO in the USA. He is an accredited IB workshop leader and facilitates workshops, both 'face-to-face' and online, on the IB Continuum and the Diploma, has contributed ideas and content to IB documentation, and also teaches (and was an examiner for) TOK (Theory of Knowledge) in the IBDP. In 1997-98, he was school/youth library adviser with the then Library Association, in London. 